\title{
Spatial-temporal Analysis of Gummosis in Three Cashew Clones at Northeastern Brazil
}

\author{
Alex Q. Cysne ${ }^{1}$, José E. Cardoso ${ }^{1}$, Aline de Holanda N. Maia ${ }^{2}$ and Fabio C. Farias ${ }^{1}$ \\ Authors' addresses: ${ }^{1}$ Laboratório de Fitopatologia, Embrapa Agroindústria Tropical, Rua Dra, Sara Mesquita 2270, \\ Fortaleza, CE, Brazil; ${ }^{2}$ Embrapa Meio Ambiente, Rodovia Campinas-Mogi Mirin, km 127.5, Jaguariúna Campinas, SP, \\ Brazil (correspondence to J. E. Cardoso. E-mail: emilson@cnpat.embrapa.br) \\ Received August 21, 2009; accepted December 10, 2009
}

Keywords: Anacardium occidentale, Lasiodiplodia theobromae, epidemiology, spatial pattern

\begin{abstract}
The cashew gummosis caused by the fungus Lasiodiplodia theobromae is one of the most important disease of cashew in the northeast of Brazil. The lack of studies about method of early detection, pathogen dissemination, host predisposition, mechanisms of attack and defence and efficient control measures assures this disease as a limiting factor as to growing of cashew under semi-arid conditions. Therefore, the characterization of spatial patterns of gummosis development under commercial orchards may provide important insights into the mechanisms involving in dissemination and disease progress of this disease, as well as in the understanding of dynamic of host, pathogen and environmental interactions for this pathossystem. This work aimed to characterize gummosis temporal and special dynamics in three commercial orchards of cashew clones of cashew with different levels of susceptibility by studying the special arrangement of diseased plants. Disease incidence and severity, quantified determined by a descriptive scale in clones BRS 226 (resistant), Embrapa 51 (slightly resistant) and Faga 11 (susceptible) in a commercial orchard located in Pio IX district (Piaui state, Brazil), were monitored and mapped. Data were collected within three blocks of 90 plants for each clone. Indices of dispersion were estimated to study the spatial dynamic. The dynamics and structure of gummosis foci were also analysed. As expected, data showed different degrees of gummosis incidence and severity for the three clones. Even under different levels of disease, a random dispersion pattern model of dispersion could be observed at the beginning of epidemic for all clones. However, as disease develops, a clustered model is likely to fit. The increase in disease incidence resulted from the increasing in both focus number and size.
\end{abstract}

\section{Introduction}

Cashew gummosis caused by Lasiodiplodia theobromae (Pat.) Griff. \& Maubl. was first reported early in 1990
(Freire 1991) and soon became one of the most important disease of cashew (Anacardium occidentale L.) in semi-arid northeastern Brazil. As a destructive disease, cashew gummosis had drawn the attention of research specialists for its potential adverse impact on cashewgrowing industry in Brazil.

Gummosis symptoms consist of trunk and woody branch cankers and dieback. Cankers may eventually ooze a gum-like resin. Dark brown-to-black region above the bark, reaching the cortical layer of vascular cambium, is seen when transverse or longitudinal cuts are made in the trunk and woody branches (Freire et al. 2002, 2004; Freire and Cardoso 2003). If canker spread remains unchecked, it eventually leads to the death of the whole tree. Diseased plants are observed after 12 months from planting and are easily identified on the orchard by slow growth, yellowing of branches and bleeding cankers (Cardoso et al. 2004). Recommended control measures are removal of infected branches by pruning, surgical removal of cankers followed by copper fungicide application. Cashew clones resistant to gummosis have recently been identified (Cardoso et al. 2006; Paiva et al. 2008).

Lasiodiplodia theobromae, the causal agent, is a wellknown opportunistic fungus, which has been found in association with many plant species in the tropics and subtropics (Punithaligam 1980).

Considerable progress has been achieved in the area of spatial and temporal analysis of disease epidemics over the last two decades (Campbell 1998; Madden et al. 2007). Spatial pattern in plant pathology refers to the arrangement of pathogens, diseased or infected plants or other components of pathossystems in relation to each other (Madden et al. 2007). Indeed, it is the first step in understanding ecological processes of plant disease as it relates to direct and indirect interactions among pathogen, host, environment and man. The analysis of spatial patterns is an attempt to infer about dispersal mechanisms as influenced by environmental 
factors. Therefore, it is critical to understand the mechanisms of survival and spread of the pathogen, needed for subsidizing strategies of diseases management.

Indices of dispersion or aggregation are a measure of the degree of spatial aggregation in a population. The variance : mean ratio (V/M) is the simplest index of dispersion and forms the conceptual basis for many other indices (Campbell and Madden 1990). Expected values of V/M of a population sample indicate either regular $(\mathrm{V} / \mathrm{M}<1)$, random $(\mathrm{V} / \mathrm{M}=1)$ ) or aggregated $(\mathrm{V} / \mathrm{M}>1)$ patterns as well as its degree of clustering of diseased plants (Davis and Brown 1996; Nelson 1996).

Analyses of dynamic and structure of foci in a single field have been suggested as an alternative to simplify the analysis of spatial data for describing epidemics and to encourage the study of epidemics based on populations of disease foci, rather than as populations of diseased individuals (Nelson 1996). A focus has been defined as a set of diseased units such that, for any unit in the set, one of its adjacent neighbouring sites also is contained in the set, where an adjacent neighbour site can be an adjacent site on the left, right, up, down or one of the four diagonally adjacent sites (Nelson 1996). Through this method, it is possible to determine a reasonable number of epidemic descriptors, such as focus number (FN), size and form. The proximity index is defined as focus size divided the maximum row and column distances spanned by a focus. Focus form may be used as an indicator of focus compactness. Furthermore, these analyses may complement information obtained from other spatial analysis techniques (Jesus Junior and Bassanezi 2004). This technique has been used to study the citrus variegated chlorosis (CVC) (Laranjeira et al. 1998), citrus canker (Bergamin Filho et al. 2001), citrus sudden death (Jesus Junior and Bassanezi 2004) and verticillium wilt of mint (Johnson et al. 2006).

As a cashew pathogen, however, L. theobromae has only been described recently, thus studies on the spatial and temporal dynamics have not been done yet. Furthermore, neither the mechanisms of dissemination nor the pattern of pathogen spread is known. Studies on spatial and temporal patterns and analyses on the dynamic and the structure of foci may contribute to assess to unknown aspects of cashew gummosis under epidemic pressure. The objective of this work was to characterize patterns of spatial and temporal dispersion of cashew gummosis in three commercial clones with different levels of resistance to corroborate the potential use of disease management practices.

\section{Materials and Methods}

The study area was located at a commercial farm orchard in Piaui state, northeast Brazil $\left(6^{\circ} 43^{\prime} \mathrm{S}\right.$ Latitude, $40^{\circ} 35^{\prime} \mathrm{W}$ Gr, longitude and $730 \mathrm{~m}$ altitude), average temperature of $24^{\circ} \mathrm{C}$ (ranging from 18 to $36^{\circ} \mathrm{C}$ ) and average rainfall of $609.7 \mathrm{~mm}$. The type of soil in the area is Alic Yellow Latosol with $\mathrm{pH}$ of 4.1 .

The spatial pattern of cashew gummosis was visually monitored as incidence of symptomatic plants in three cashew clones, namely, BRS 226 (highly resistant), Embrapa 51 (moderate resistant) and Faga 11 (susceptible), between August 2003 and September 2007. Plants were grown in a $7 \times 7 \mathrm{~m}$ squared spacing. All plants originated from clonal propagules grafted on rootstocks produced from seeds obtained from open-pollinated plants of the same commercial clone (CCP 06). Data were collected from three sampling plots consisting of 90 plants each (i.e. nine rows of 10 plants). Disease evaluation started from the appearance of the first symptom and therein at bimonthly intervals. The location of each diseased plant and the date when the symptoms appeared were recorded and mapped. A disease severity score (DSS) was also attributed to each plant accordingly to a descriptive severity scale: DSS $=0$, no symptoms; DSS $=1$, small and few cankers on trunk and branches, small cracks without gum exudation; DSS $=2$, larger, cracked cankers on trunks and branches, reaching up to $1 / 3$ of diameter, with little or no gum exudation; DSS $=3$, cracked cankers, larger than $1 / 3$ of diameter with abundant gum exudation; or DSS $=4$, cracked cankers completely girdling trunk or branches, foliage yellowing, dieback and gum exudation; (Cardoso et al. 1998).

Dispersion index $(D)$, which consisted of the $\mathrm{V}$ $\left(s^{2}\right) \mathrm{M}(\bar{x})$ ratio, was estimated for each sampling plot. Binary (presence/absence) spatial maps of gummosis were prepared for all assessment dates for each plot. For random patterns, $D$ has an approximate chisquared distribution with $n-1$ degrees of freedom, where $n$ is the number of evaluated plants. Therefore, values of $D$ greater than the critical chi-squared value indicate that the $\mathrm{V} / \mathrm{M}$ ratio is significantly larger than 1 and, thus, indicate aggregation (Hoel 1943; Upton and Fingleton 1985). The SAS package (SAS, Chapell Hill, NC, USA) was used to calculate the chi-squared statistic to evaluate goodness-of-fit of the data to the Poisson and negative binomial.

Based on maps of disease incidence, the analysis of focus structure was performed for each plot, using the method described by Nelson (1996) and Laranjeira et al. (1998). It was considered only adjacent symptomatic plants within rows and across rows belonging to the same focus. Foci formed by only one diseased plant were referred to as unitary foci.

Number of foci (NF), number of unitary foci (NUF), mean number of plants per focus (NPF) and maximum number of rows $\left(\mathrm{lr}_{i}\right)$ and columns $\left(\mathrm{lc}_{i}\right)$ in the focus $i$ were calculated for all assessment dates, in each plot. The mean index form (MIF) and the index of focus compactness (ICF) were estimated from those data by Eqns 1 and 2, respectively.

$$
\begin{array}{r}
\mathrm{MIF}=\frac{\sum\left(\frac{1 \mathrm{r}_{i}}{\mathrm{lc}_{i}}\right)}{\mathrm{NF}} \\
\mathrm{ICF}=\frac{\sum\left(\frac{\mathrm{NPF}_{i}}{\mathrm{lc}_{i} \times \mathrm{lf}_{i}}\right)}{\mathrm{NF}}
\end{array}
$$




\section{Results}

Gummosis was first detected at 19, 26 and 29 months after planting (MAP) in cashew clones FAGA 11, BRS 226 and Embrapa 51, respectively. Dispersion indexes for all clones throughout 50 months of evaluation are presented in Fig. 1. In the clone BRS 226, occurrence was very low, and only in one of the three plots, the disease showed a random dispersion pattern of dispersion, accordingly to the dispersal index $(D)$. The disease slightly increased by 28 MAP, but at very low levels during the following months of evaluation in all three plots, never reaching $5 \%$ of occurrence (Fig. 2) with no changes on dispersion pattern. In Embrapa 51, the disease was observed in one plot by 29 MAP, but only after 44 MAP in all three plots. Between 38 to $44 \mathrm{MAP}$, two of three plots already showed an aggregated dispersion pattern, and by 55 MAP, these two plots changed to a uniform pattern, clearing demonstrating changes in spatial arrangement as epidemics develops. During most of the monitoring time, however, a random pattern was observed, and in one of three plots, there was no change in spatial pattern after disease detection, during the whole evaluation period. In the FAGA 11, the disease was detected earlier than it was in the other

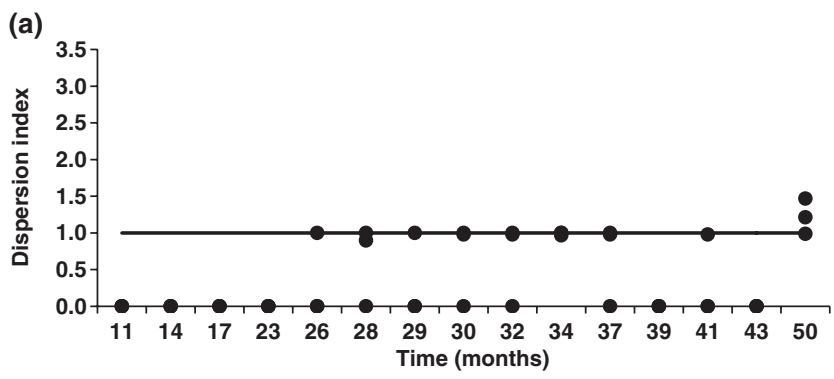

(b)

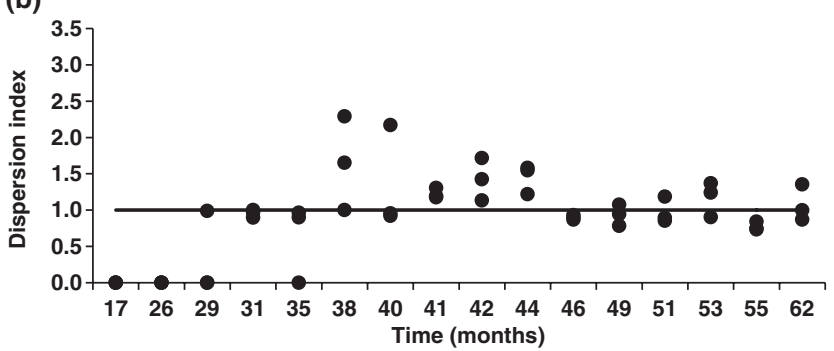

(c)

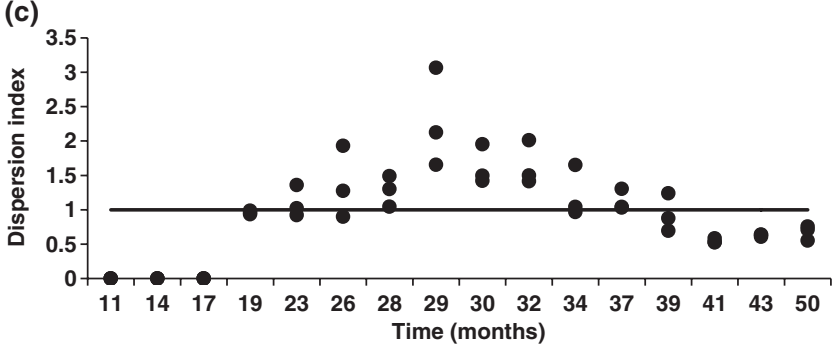

Fig. 1 Gummosis dispersion index $\left(D=s^{2} / \bar{x}\right)$ for three cashew clones during the evaluation period (11-50 months after planting) in the same orchard: BRS 226 (a), Embrapa 51 (b) and FAGA 11 (c) Each point represents mean $D$ arising from three plots of 90 plants for each clone

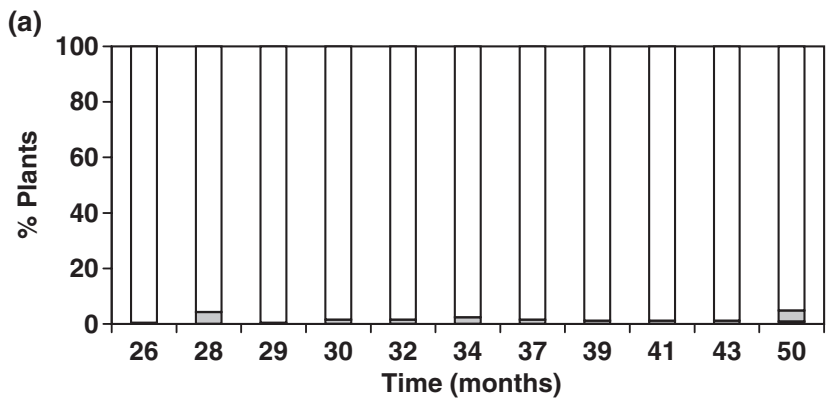

(b)

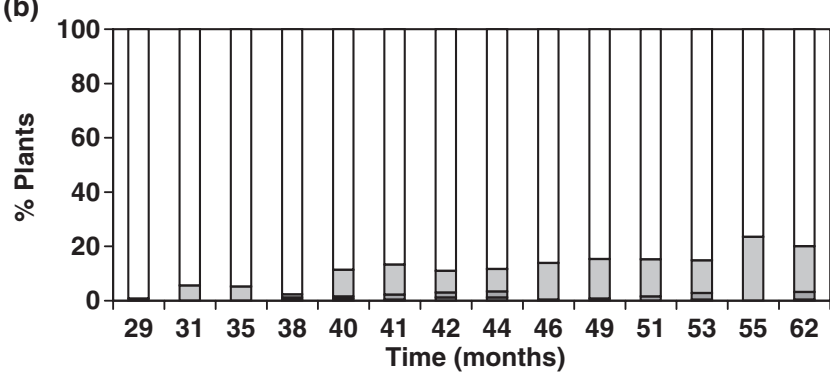

(c)

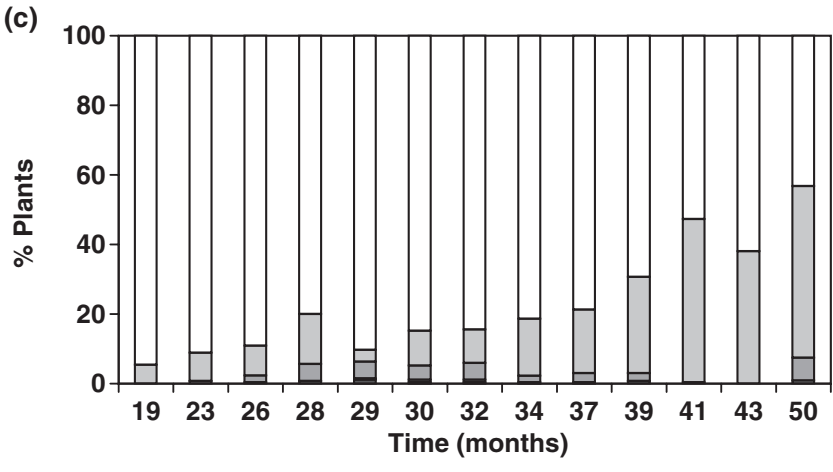

$\square$ Class $4 \square$ Class $3 \square$ Class $2 \square$ Class $1 \square$ Class 0

Fig. 2 Percentage of plants in each of the five gummosis severity classes (0-4) for each evaluated cashew clone: BRS 226 (a), Embrapa 51 (b) and FAGA 11 (c). Evaluation period was from 19 to 50 months in the same orchard. Each bar represents mean percentage coming from three plots of 90 plants for each clone

clones. By 19 MAP, symptoms were already observed in all plots. A random dispersion pattern was observed at the beginning of epidemics ( 5 months), then the clustered pattern prevailed throughout most of the period of evaluation (Fig. 1).

Percentage of plants within each of the five gummosis severity classes $(0-4)$, during the evaluation period, for each evaluated clone are presented in Fig. 2.

During whole evaluation period, the clone BRS226 showed only a small number of diseased plants, thus most foci were composed of only one or two plant. The NF and the NUF showed similar patterns as unitary foci predominated, they directly influenced on the shape of the curve (Fig. 3a1,a2). The clone Embrapa 51 also showed similar patterns for NF and NUF curves (Fig. 3b1,b2), but they started to differ by 55 MAP, when disease incidence reached $22 \%$, NF increased and NUF decreased. As new NUF emerge by $51 \mathrm{MAP}$, an increase in the NF and reduction in NPF were again observed. Later, foci started to merge 


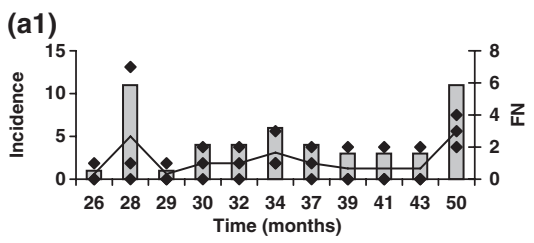

(b1)

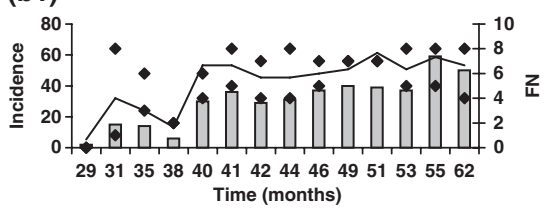

(c1)

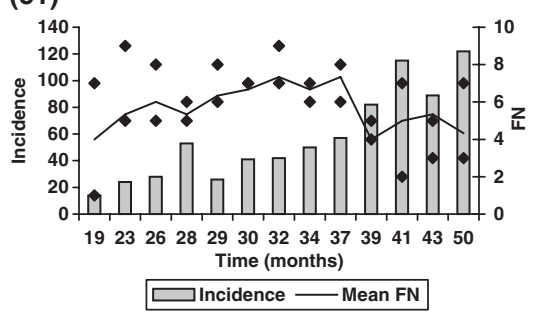

(a2)

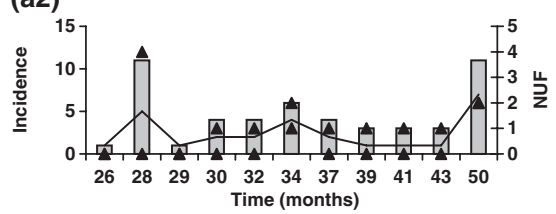

(b2)

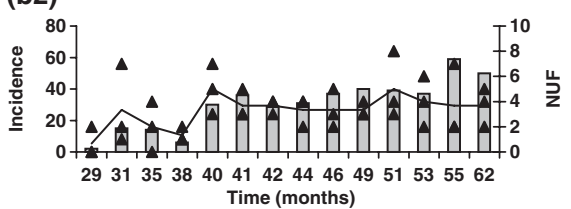

(c2)

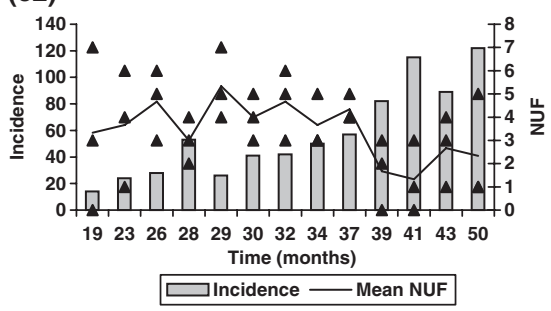

number and number of unitary focus for the cashew clones evaluated: BRS 226 (a1 and a2), Embrapa 51 (b1 and b2) e FAGA 11 ( $\mathrm{c} 1$ and $\mathrm{c} 2$ ). The evaluation period was from 19 to 50 months after planting. Each bar represents the mean incidence coming from three plots of 90 plants for each clone
Dispersion analyses based on the simple dispersion index $(D)$ seemed to be sufficient to describe the spatial pattern of gummosis clone BRS 226. For the other
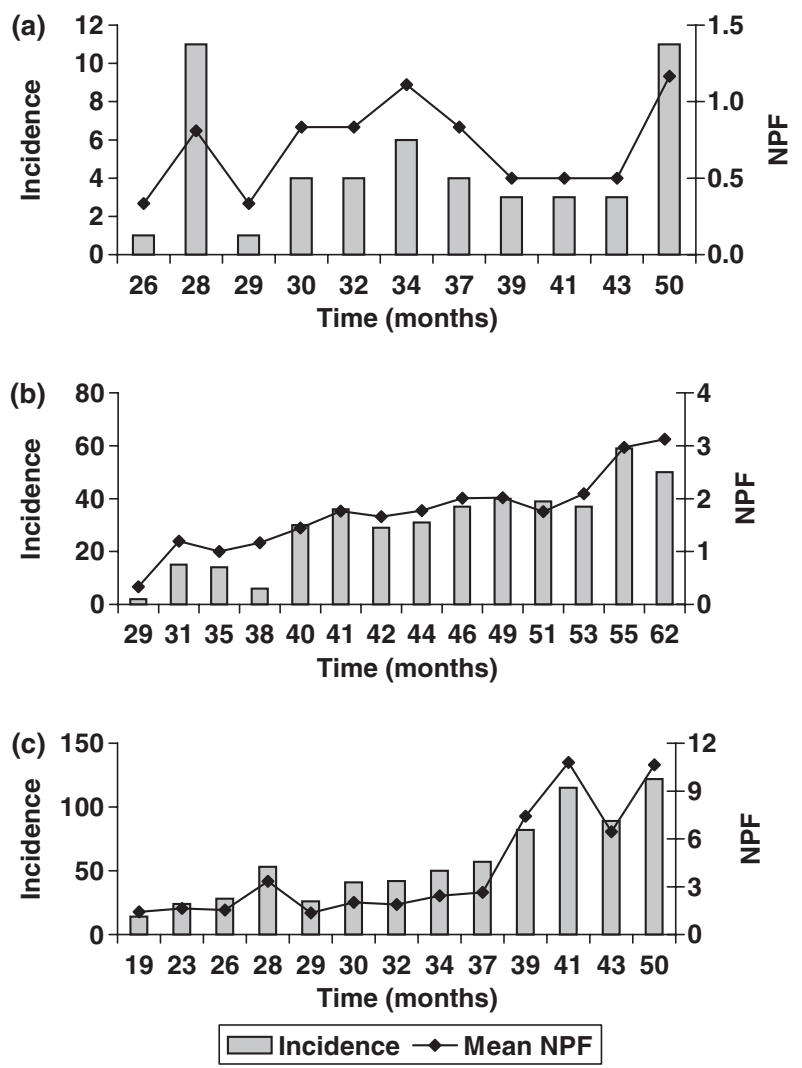

Fig. 4 Gummosis progress and number of diseased plants per focus (NPF) for each of cashew clones evaluated: BRS 226 (a), Embrapa 51 (b) e FAGA 11 (c). The evaluation period was from 19 to 50 months after planting. Each bar (or dot) represents the mean incidence (or NPF) coming from three plots of 90 plants for each clone 
(a)

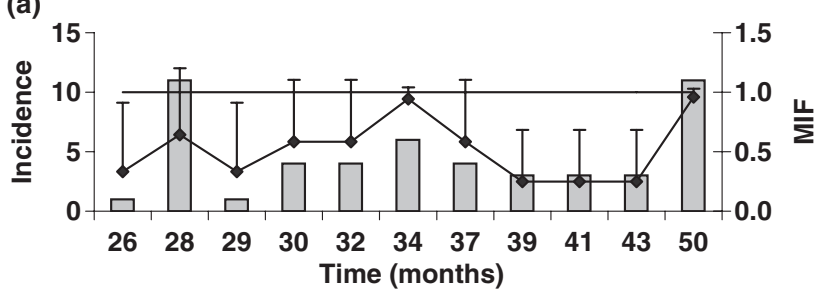

(b)

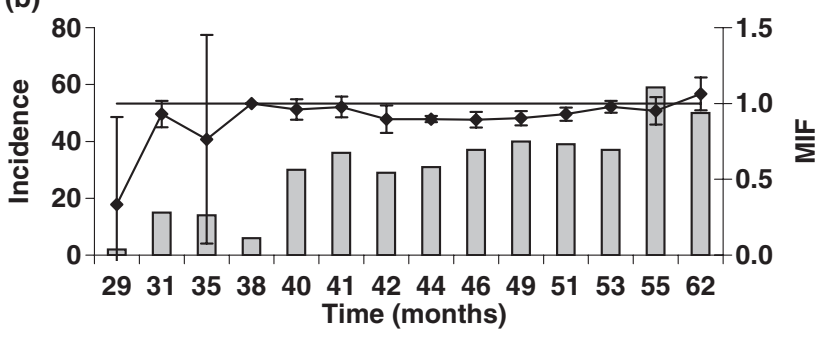

(c)

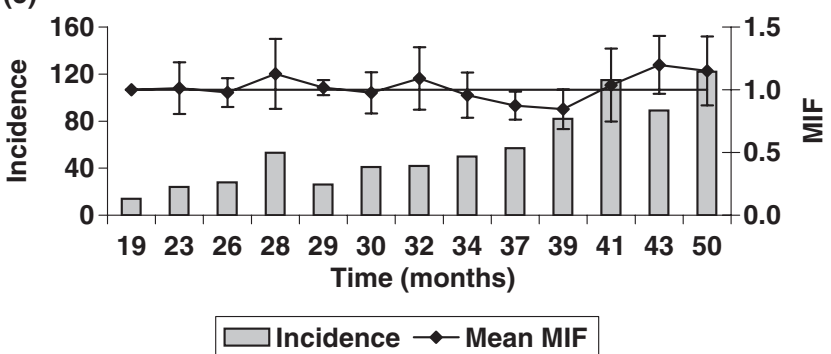

Fig. 5 Gummosis progress and index of focus form (MIF) for cashew clones evaluated: BRS 226 (a) Embrapa 51 (b) e FAGA 11 (c). The evaluation period was from 19 to 50 months after planting. Each bar represents the mean incidence coming from three plots of 90 plants for each clone. Vertical bars correspond to MIF standard errors

clones, even without a clear tendency in some observations, in general, that index adequately described the disease spread, thus confirming that early tests based on V/M ratio are normally sensitive to aggregated model, although may detect not randomized pattern where other tests may fail (Greig-Smith 1983). Nevertheless, Laranjeira et al. (2004) raised a limitation of this index as not capable of characterizing dispersal patterns for CVC in three different regions of São Paulo state in Brazil, even being superior to the one based on Taylor power law (Laranjeira et al. 2004). Ferreira (2006), working with Colletotrichum - coffee pathossystem, obtained a D value close to, but different from the observed model on the map of disease distribution.

In the present study, analysis based on dispersion index showed a large difference on disease behaviour among different clones evaluated. In the BRS 226, when the disease incidence was low, a random pattern prevailed, while in the Embrapa 51, the pattern varied from aggregated to random with prevalence to the least. As for FAGA 11, disease started with a random pattern, moving towards the aggregate one. These differences slowed that different host reactions can trigger different spatial and temporal patterns (Nelson 1996).

It is very probable that these differences are associated to the different disease reactions by the clones
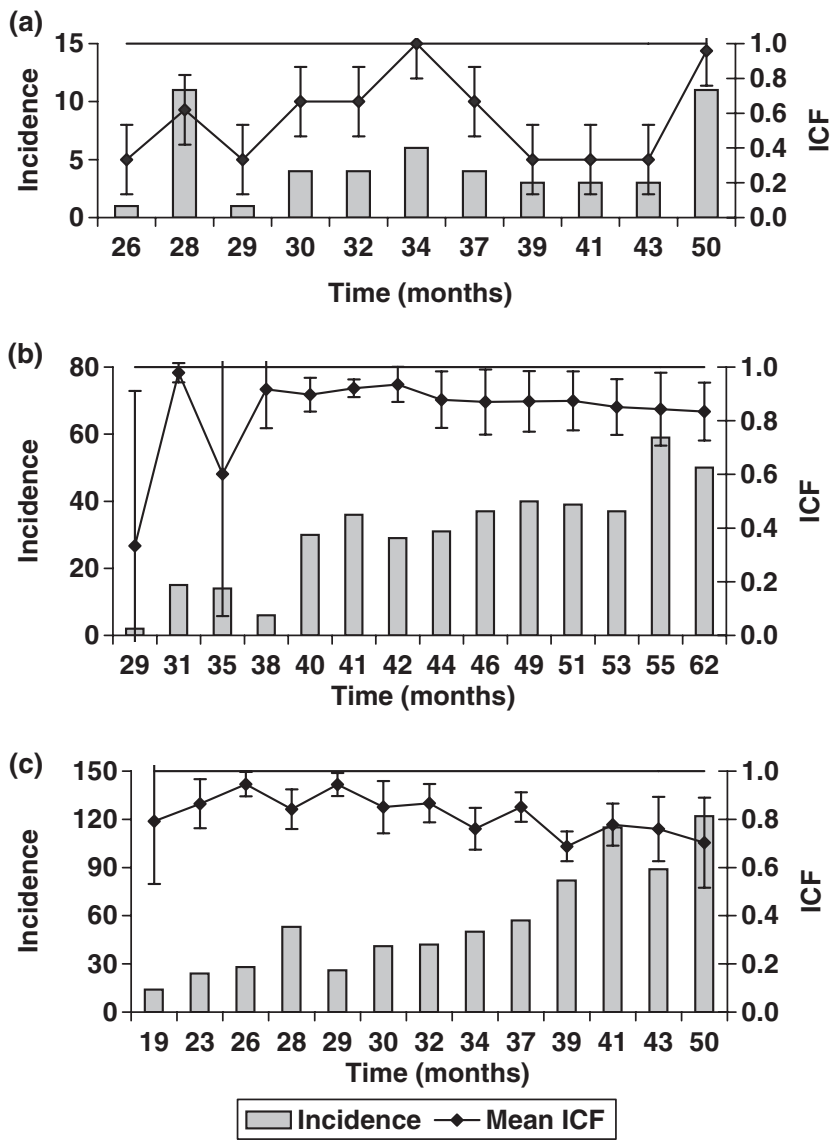

Fig. 6 Gummosis progress and index of focus compactness (ICF) for the cashew clones evaluated: BRS 226 (a) Embrapa 51 (b) e FAGA 11 (c). The evaluation period from 19 to 50 months after planting. Each bar (or dot) represents the mean incidence (or ICF) coming from three plots of 90 plants for each clone. Vertical bars correspond to ICF standard errors

studied. Resistant reaction of BRS 226 early described (Cardoso et al. 2006; Paiva et al. 2008) was confirmed (Figs 2-4). Clone Embrapa 51, which had no previous known reaction, showed a moderate resistance as it only reached approximately $20 \%$ incidence by the end of evaluation period. Clone FAGA 11 clearly showed a highly susceptible reaction.

Considering all tested clones, the random dispersion model is the most appropriated one even considering differences in the index of dispersion. This tendency points out to the previous hypothesis that the pathogen is first introduced via randomly infected planting materials. Lasiodiplodia theobromae has been reported as an endophytic fungus (Baird and Carling 1998; Cilliers 1993; Mohali et al. 2005; Mullen et al. 1991; Rubini et al. 2005) or as latent pathogen (Freire et al. 2004; Khanzada et al. 2004; Correa and Costa 2005; Cardoso et al. 2009).

The data on focus dynamics show that for both clones BRS 226 and Embrapa 51, the NF, the NUF and the NPF increased with increase in disease incidence, suggesting that disease enhance by both newly developed foci and growth of foci. However, when reaches 14\% incidence, focus joined in Embrapa 51, 
thus FN was reduced. In the clone FAGA 11, similar disease evolution occurred but earlier than with the other clones.

All clones evaluated, although presenting different values of NF, NUF and NPF, which explains the different reactions to the disease, showed similar patterns such as form of spread where NUF is the primary assessment to increase. Therefore, the study of focus dynamic corroborates the information provided by dispersion indexes. Unitary foci were responsible for the starting out of the epidemics. Further, they become source of inoculum to nearby plants.

The starting out of the epidemics was observed in isolated plants, reinforcing the hypothesis of primary way of transmission by propagating material similar to what occurs with Colletotrichum - coffee pathossystem in which dissemination is accomplished by seed (Ferreira 2006).

The inverse relationship between NUF and NPF was associated to the disease incidence, pointing out to the contagious transmission from plant to plant after introduction of disease into the orchard. Similar results were obtained with Citrus sudden death (Jesus Junior and Bassanezi 2004), where a random pattern of distribution in the beginning was followed by aggregation. Such evolution was associated with a arthropod vector from outside the orchard as the primary source of inoculum. In the case presented here, the random pattern in the beginning may be due to inoculum introduction via planting material as stated before. Lasiodiplodia theobromae has been associated to wound or stressed-weakened plants (Britton and Hendrix 1986; Baird and Carling 1998). Therefore, disease development is inevitably as both stress factors are very common in the semi-arid region where the work was conducted, especially after the first economical yield, which occurs after the second year (Cardoso et al. 2006). Secondary spread from plant to plant may result via cutting machinery or small animals such as birds and monkeys (Olunloyo and Esuroso 1975; Punithalingam 1976; Prakash and Raoof 1989; Tavares et al. 1994).

Focus form analyses showed different temporal patterns for the clones evaluated. Diseased plants along rows predominate in BRS 226 and Embrapa 51, while in FAGA 11, there was no clear evidence for this type of focus shape (Fig. 5). This is likely to occur due to the mechanism of penetration by machinery wound for former clones and other additional ways for the susceptible FAGA 11. The transmission of this pathogen through cutting machinery has been demonstrated (Cardoso et al. 1998). Infection of FAGA 11 was favourable by its susceptibility because the MIF was different from the other clones. The MIF had an isodiametric form in most of observations when considered below 30\% disease incidence; above this, it was not possible to establish a focus form (Fig. 5).

The focus compactness (ICF) decreased by increase in disease incidence in FAGA 11, similarly to what was observed in studies on citrus diseases (Laranjeira et al. 1998; Jesus Junior and Bassanezi 2004). The ICF for Embrapa 51 and BRS 226 increased to close to 1.0 as disease incidence increased. This might be consequence of disease resistance of these clones, whereas aggregation of diseased plants is low as greater number of isolated diseased plants is observed (Ferreira 2006).

Results on the focus dynamics and structure for the three clones evaluated showed differences which can be associated with the level of resistance or susceptibility to gummosis. A high density of susceptible plants seems to be necessary for detailed studies on spatial analysis as it favours disease development due the enhancement of both the inoculum potential and the rate of transmission of the disease (Carvalho and Chalfoun 1998).

Based on the results presented, gummosis management practices are resistant clones and preventing the introduction of L. theobromae to crop production areas such as pathogen-free propagative parts should be emphasized. Hence, the applicability of this later practice needs to develop a method of detecting and cleaning the plant tissue.

\section{Acknowledgements}

Research reported herein was supported in part by Brazilian Consetho Nacional de Desenvolvimento Científico e Tecnológico (CNPq) and Universidade Federal do Ceará (UFC). We are grateful to direction and staff of Companhia Industrial de Óleos do Nordeste (CIONE) for providing orchards and facilities for fieldwork.

\section{References}

Baird R, Carling D. (1998) Survival of parasitic anal saprophytic fungi or intact senescent cotton roots. J Cotton Sci 2:27-34

Bergamin Filho A, Amorim L, Gottwald TR, Laranjeira FF. (2001) Spatial distribution of citrus canker in São Paulo - Brazil. In: Anon. (ed) Proc 8th International Workshop on Plant Disease Epidemiology, 4-6 April 2001. Ouro Preto, MG, Brazil, p 29.

Britton KO, Hendrix FF. (1986) Population dynamics of Botryosphaeria spp. in peach gummosis canker. Plant Disease 70:134136.

Campbell CL. (1998) Disease progress in time: modeling and data analysis. In: Jones DG. (ed) The epidemiology of plant diseases. Dordrecht, the Netherlands, Kluwer Academic Publishers, pp 181206.

Campbell CL, Madden LV. (1990) Introduction to Plant Disease Epidemiology. New York, Wiley, 532 pp.

Campbell CL, Noe J. (1985) The spatial analysis of soilborne pathogens and root diseases. Annu Rev Phytopathol 23:129-148.

Cardoso JE, Bezerra MA, Viana FNP, Sousa TRM, Cysne AQ, Farias FC. (2009) Ocorrência endofítica de Lasiodiplodia theobromae em tecidos de cajueiro e sua transmissão por propágulos. Summa Phytopathologica 35:262-266.

Cardoso JE, Freire FCO, Sá FT. (1998) Disseminação e controle da resinose em troncos de cajueiro decepados para substituição de copa. Fitopatol Bras 23:48-50.

Cardoso JE, Vidal JC, Uchoa CN, Alencar ES, Silva RC. (2003) Diagnóstico do sistema produtivo do cajueiro no sudeste do Piaú́. In: Anon. (ed) Comunicado técnico 83. Fortaleza, CE, Brazil, Embrapa Agroindústria Tropical, pp 1-4.

Cardoso JE, Santos AA, Rossetti AG, Vidal JC. (2004) Relationship between incidence and severity of cashew gummosis in semiarid north-eastern Brazil. Plant Pathol 53:363-367.

Cardoso JE, Paiva JR, Cavalcanti JJV, Santos AA, Vidal JC. (2006) Evaluation of resistance in dwarf cashew to gummosis in northeastern Brazil. Crop Prot 25:855-859.

Carvalho VL, Chalfoun SM. (1998) Manejo integrado das principais doenças do cafeeiro. Informe agropecuário - EPAMIG 19:27-35. 
Cilliers A. (1993) A review of Lasiodiplodia theobromae with particular reference to its occurrence on coniferous seeds. South African Forestry Journal 166:47-52.

Correa MS, Costa JLS. (2005) Dispersão anemófila do fungo Lasiodiplodia theobromae em plantações de coqueiro. Fitopatol Bras 30: $150-154$.

Davis RI, Brown JF. (1996) Epidemiology and management of kava dieback caused by cucumber mosaic cucumovirus. Plant Dis 80:917-921.

Ferreira JB. (2006) Análise da dinâmica, estrutura de focos e arranjo espacial da mancha manteigosa em campo. In: Aspectos histo patológicos, epidemiologia e controle da mancha manteigosa em Coffea arabica L. Lavras, MG, Brazil, Universidade Federal de Lavras, PhD Thesis, pp 114-138.

Freire FCO. (1991) A resinose do cajueiro. In: Anon. (ed) Caju Informativo 4. Fortaleza, CE, Brazil, Embrapa Agroindústria Tropical, pp 1-2.

Freire FCO, Cardoso JE. (2003) Doenças do cajueiro. In: Anon. (ed) Doencas de fruteiras tropicais de interesse agroindustrial. Brasília, DF, Brazil, Embrapa Informação Tecnológica, pp 192-226.

Freire FCO, Cardoso JE, Santos AA, Viana FMP. (2002) Diseases of cashew (Anacardium occidentale L.) in Brazil. Crop Prot 21:489-494.

Freire FCO, Viana FMP, Cardoso JE, Santos AA. (2004) Novos hospedeiros do fungo Lasiodiplodia theobromae no Estado do Ceará. In: Anon. (ed) Comunicado técnico 91. Fortaleza, CE Brazil, Embrapa Agroindústria Tropical, pp 1-6.

Greig-Smith P. (1983) Quantitative plant ecology. Berkeley, CA, USA, University of California Press.

Hoel PG. (1943) On indices of dispersion. Ann Math Stat 14:155162.

Jesus Junior WC, Bassanezi RB. (2004) Análise da dinâmica e estrutura de focos da morte súbita dos citros. Fitopatol Bras 29:399 405.

Johnson DA, Zhang H, Alldredge JR. (2006) Spatial pattern of Verticillium wilt in commercial mint fields. Plant Dis 90:789-797.

Khanzada MA, Lodhi AM, Shahzad S. (2004) Mango dieback and gummosis in Sindh, Pakistan caused by Lasiodiplodia theobromae. Plant Health Prog Disponível em: http://www.plantmanagementnet work.org/sub/php/diagnosticguide/2004/mango/Shahzad.pdf (accessed 25 June 2006).

Laranjeira FF, Bergamin Filho A, Amorim L. (1998) Dinâmica e estrutura de focos da clorose variegada dos citros (CVC). Fitopatol Bras 23:36-41.
Laranjeira FF, Bergamin Filho A, Amorim L, Gottwald TR. (2004) Dinâmica espacial da clorose variegada dos citros em três regiões do Estado de São Paulo. Fitopatol Bras 29:56-65.

Madden LV, Hughes G, Van den Bosch G. (2007) The study of plant disease epidemics. St. Paul, MN, USA, APS Press.

Mohali S, Burgess TI, Wingfield MJ. (2005) Diversity and host association of the tropical tree endophyte Lasiodiplodia theobromae revealed using simple sequence repeat markers. Forest Pathology 35:385-396.

Mullen JM, Gilliam CH, Hagan AK, Morgan-Jones G. (1991) Canker of dogwood caused by Lasiodiplodia theobromae, a disease influenced by drought stress or cultivar selection. Plant Dis 75:886-889.

Nelson SC. (1996) A simple analysis of disease foci. Phytopathology 86:332-339.

Olunloyo OA, Esuroso OF. (1975) Lasiodiplodia floral shoot dieback disease of cashew in Nigeria. Plant Dis Rep 59:176-179.

Paiva JR, Cardoso JE, Mesquita ALM, Cavalcanti JJV, Santos AA. (2008) Desempenho de clones de cajueiro-anão precoce no semi-árido do Estado do Piauí. Ciênc Agron 39:295-300.

Prakash O, Raoof MA. (1989) Dieback disease of mango (Mangifera indica) its distribution, incidence, cause and management. Fitopatol Bras 14:207-215.

Punithalingam E. (1976) Botryodiplodia theobromae. Kew, Surrey, UK, CMI, Description of Pathogenic Fungi and Bacteria No 519, pp 1-3.

Punithaligam E. (1980) Plant diseases attributed to Botryodiplodia theobromae Pat. Bibliotheca Mycologia 71:1-123.

Rubini MR, Silva-Ribeiro RT, Pomella AWV, Maki CS, Araújo WL, Santos DRD, Azevedo JL. (2005) Diversity of endophytic fungal community of cacao (Theobroma cacao L.) and biological control of Crinipellis perniciosa, causal agent of Witches' Broom Disease. International Journal of Biological Sciences 1:24-33.

Tavares SCC, Barreto DSB, Amorim LR. (1994) Levantamento do comportamento de Botryodiplodia theobromae em videira na região semi-árida. In: Anais do XII Congresso Brasileiro de Fruticultura. Salvador, BA, Brazil, 27 November-2 December 1994, pp 933 934.

Upton GJG, Fingleton B. (1985) Spatial Data Analysis by Example: Point Pattern and Quantitative Data. New York, Wiley, 410 pp. 